\title{
THE EFFECT OF CLIMATE CHANGE ON THE POPULATION OF SYCAMORE LACE BUG (CORYTHUCA CILIATA, SAY, TINGIDAE HETEROPTERA) BASED ON A SIMULATION MODEL WITH PHENOLOGICAL RESPONSE
}

\author{
M. LADÁNYI* - L. HUFNAGEL \\ Corvinus University of Budapest, Department of Mathematics and Informatics \\ H-1118 Budapest, Villányi út 29-43., Hungary \\ (phone: +36-1-482-6261; fax: +36-1-466-9273) \\ *e-mail:marta.ladanyi@uni-corvinus.hu \\ (Received $10^{\text {th }}$ Sep 2005, accepted $10^{\text {th }}$ Oct 2006)
}

\begin{abstract}
Climate change affects on insect populations in many ways: it can cause a shift in geographical spread, abundance, or diversity, it can change the location, the timing and the magnitude of outbreaks of pests and it can define the phenological or even the genetic properties of the species. Long-time investigations of special insect populations, simulation models and scenario studies give us very important information about the response of the insects far away and near to our century. Getting to know the potential responses of insect populations to climate change makes us possible to evaluate the adaptation of pest management alternatives as well as to formulate our future management policy. In this paper we apply two simple models, in order to introduce a complex case study for a Sycamore lace bug population. We test how the model works in case the whether conditions are very different from those in our days. Thus, besides we can understand the processes that happen in present, we can analyze the effects of a possible climate change, as well.
\end{abstract}

Keywords: climate change, insects, pest management, simulation, agriculture

\section{Introduction and Aims}

Simulation is the ultimate tool for forecasting the effect of climate and other environmental factors on the ecosystem, since the real circumstances of future cannot be examined empirically. However, it may take several years to reach the stage when these forecasts will be usable in the agriculture since the longer climate forecasts are not yet good enough [18], [15], [39]. There have been made several projects in Hungary with simulation model applications and with valuable results about the effects of climate change on the yield of arable crops [16], [17], [29], [27], [30], [31], [32], but there are very rare references on plant - pest populations.

In our paper we refer to one of our earlier population dynamical food web biomass model together with a phenology model based on the food web model [33], [34]. In the food web model the seasonal weather aspects, the nutrient content of soil and the biotic interactions are considered. To simulate the interactions, a discrete difference equation system was used. The general equation of the model is based on three terms: the first one is to express the activity of the individual depending on the temperature, the second one is to describe the effect of the quality and the quantity of the nutrient of the populations and the third one is to display the effect of the predators.

Besides quantitative (biomass) changes, however, there are also seasonal qualitative changes during the evolution of the entities. These changes are described by phenology. 
It is obvious to ask, how the number of entities can be derived from a given amount of biomass. More exactly, if the phenological phases of the population, together with their biological properties, are known, how can one define the number of the entities of each phenophase at a given point of time? Our phenology model is to solve this problem.

In what follows, we apply the above two models in a drastically simplified form, in order to introduce a complex case study for a Sycamore lace bug (Corythuca ciliata) population.

In addition to the foregoing, we found it very useful to ask, how the model works in case the whether conditions are very different from those in our days. Thus, besides we can understand the processes that happen in present, we can analyze the effects of a possible climate change, as well.

Sycamore lace bug can be an excellent indicator for the climate researchers as it has much less biotic interactions comparing with other native species or with species having native host. Sycamore lace bug has other advantages, too, namely, that it is monophagous in Europe and it can quite easily be monitored, due to its way of life [55], [44].

Obviously, our contemporary knowledge does not make us possible to predict the future, even for the quite well known Corythuca ciliata-Sycamore tree (Platanus hybrida) populations. A reasonable aim can be, however, to find out, what is predicted by our model for simulated weather data with different parameters for different assumptions. This aim corresponds to the aims of VAHAVA project of the Hungarian Academy of Sciences, as well as to those of international climate change projects $[4,5$, $20,21,35,54]$.

To explore the possible effects of an unknown climate change in future, we need not real but realistic alternative climate scenarios. First, we define the concept of climate scenario.

Climate scenarios are possible future climates in a set. Each of them is made consistently by applying scientific principles; however any of them has a fixed (calculable) possibility. A climate scenario is one of the possible climates and it is by no means a prediction $[3,21]$.

After having recognized the ecological consequences of climate change, together with UNEP, WMO (World Meteorological Organization) has established IPCC (Intergovernmental Panel on Climate Change) with the task of giving unbiased and detailed information about climate change and its expected effects.

During our research, we applied the principles defined by IPCC and we used some of the most commonly accepted scenarios presented in international reports. The most serious scenarios, themselves, are results of simulation models. For generating scenarios the so-called GCMs are generally used (General Circulation Model or Global Climate Model). GCMs have been successfully used to estimate the climate change on arable crops yield in Hungary in a 15- and a 30-year scenario [26].

In our research we applied six different scenarios, such as:

- - Scenario BASE is a simulated weather data series with the same conditions as we have at present.

- Scenarios GFDL2535 and GFDL5564 have been created by Geophysical Fluid Dynamics Laboratory (U.S.A.) with the assumption that $\mathrm{CO}_{2}$ concentration doubles in atmosphere. The difference between the scenarios is their resolution level. (The later has higher resolution.) 
- Three very different scenarios have been worked out by United Kingdom Meteorological Office (UKMO), namely UKHI (high-resolution equilibrium climate change experiment), UKLO (low-resolution equilibrium climate change experiment) and UKTR (high-resolution transient climate change experiment). The first two scenarios of UKMO (UKHI, UKLO) are so-called equilibrium models, that is to say, assumed that $\mathrm{CO}_{2}$-concentration doubles in atmosphere, GCM runs until an equilibrium state with stable surface temperature. The third scenario of UKMO (UKTR) is a transient model that describes the gradually changing climate assuming a gradually increasing $\mathrm{CO}_{2}$ content of atmosphere [4, 24].

Note that the results of GCMs should be scaled on the examined region with the help of empirical statistical methods [5]. In our paper, we present the results of the $15^{\text {th }}$ year of each 30-year period scenario concerning the years around 2050. The scaling of the scenarios for the region of Hungary was made in the frame of CLIVARA project (Climate Change, Climatic Variability and Agriculture in Europe). The database and the references were made available for us by professor Zs. Harnos, the Hungarian leader of the project.

To sum it up, in this paper we followed two main aims:

- To create a complex population dynamical model with phenology responses for Sycamore lace bug based on an earlier field-work [44].

- To introduce a case study for the above model applied for some widely accepted climate-change scenarios.

\section{Review of literature}

In our century increasing societal, environmental, and economic pressures force us to develop new agricultural pest management strategies. Interdisciplinary approaches have the aim to find the way, how the environmental degradation caused by the use of chemicals can be decreased, how the productivity can be increased by reducing insect and disease damage to cultivated plants, and how the competition with weeds can be reduced. Crop and forestry population system models are useful tools to examine the interrelationships among plants, pests and the environment. With simulation models we can find optimal strategies that meet individual and societal goals.

Improved techniques for managing pests require weather and insect data from thoroughly maintained monitoring as well as climate information and forecast to determine their suitability. Climatic change, including global warming and increased variability require improved analyses that can be used to assess the risk of the existing and the newly developed pest management strategies and techniques, and to define the impact of these techniques on environment, productivity and profitability. Each technique has to be evaluated whether and how it is suitable in the farming system where they are to be applied.

Nowadays, several studies are investigating the impact of climatic change on insect populations. Some of the effects can be discovered in laboratories, only (e.g. the effect of humidity [6]), some of them need field observations maintenance. The impact of climate change, moreover, alters from region to region, from species to species. Quite a lot of new methods from different disciplines are used to detect the most important 
effects. Therefore, the studies of climate change effects are considering different aspects, such as palaeontological, agricultural, medical, geological, biological as well as the aspects of forestry management. This widespread research work requires interdisciplinary cooperation of researchers from several fields [53]. We give a short review of the main approaches.

\section{The aspect of palaeontology}

One of the most important ways to find out what climate change can bring us is to look back into the very past. A few thousand years ago some regions were characterized by such kind of vegetations that existed within warming thermal conditions analogous to those today. For example, the transition from parkland vegetation and insects to the one of coniferous forest of south-western Ontario region indicates that the climate continued gradually warm through the mid-Holocene [48].

The Lateglacial-Holocen transition is characterized by major changes in the insect fauna, too, reflecting an extremely rapid climate change in South-Sweden, as well as in Swiss-Alps. In these regions the cold-adapted species assemblage was immediately replaced by temperate species [36], [37]. During the same time period most of temperate species of Chihuahuan Desert (Texas) were replaced either by desert species or more cosmopolitan taxa [12]. The above studies pointed out the dependency of the changes in climate and fauna. The question of how these kinds of responses proceed was studied by Amman [1].

\section{The approaches with models, simulations and scenarios}

Developing ecological and simulation models is a very useful tool to find out the response of a system to an event or a series of events. Ecological or meteorological models describe biological or climate properties mathematically, while simulations make a computer based models system supplied with a great amount of empirical data.

To reach his above mentioned palaeontological results in Swiss-Alps, Lemdahl [37] applied a so-called climatic reconstruction (MCR) method that simulates realistic climate data in the past. Simulated weather data, however, are most commonly used to examine the potential future effects. These approaches are called scenario studies.

The main problems that have to precede scenario studies are, nevertheless, the evaluation, the validation and verification of the applied models. Though several models have been developed e.g. for the carbon budget of boreal forests, enormous problems remain in incorporating pest effects in these models. These problems have their origins, partly in scaling. The common problems of verification and validation of model results are particularly troublesome in projecting future productivity [56].

A main point of scenario studies is, therefore, how the applied model should be scaled. Hanson [19] noticed that although early model predictions of climate change impacts suggested extensive forest dieback and species migration, more recent analyses suggest that catastrophic dieback will be a local phenomenon, and changes in forest composition will be a relatively gradual process. Better climate predictions at regional scales, with a higher temporal resolution (months to days), coupled with carefully designed, field-based experiments that incorporate multiple driving variables (e.g. temperature and $\mathrm{CO}_{2}$ ); will advance our ability to predict the response to climate change.

Time-dependent models developed at fine spatial resolution of experimental studies are widely used to forecast how plant - insect populations will react over large spatial 
extents. Usually the best data available for constructing such models comes from intensive, detailed field studies. Models are then scaled-up to coarser resolution for management decision-making. Scaling-up, however, can affect model predictions and dynamical behaviour which can result misinterpretation of model output. The potential negative consequences of scaling-up deserve consideration whenever data measured at different spatial resolutions are integrated during model development, as often happens in climate change research [13].

Chen [7] investigates the integrated effects of insect infections, management practices, carbon cycle and climatic factors both at regional and global scales.

To see that there can be great difference between the responses of even similar species, we refer to Conrad et al [8]. They examined the garden tiger moth (Arctia caja) that was widespread and common in the UK in the last century, but its abundance fell rapidly and suddenly after 1984 . The most UK butterflies are expected to increase under UK climate change scenarios of global warming. Contrary to them, garden tiger is predicted to decrease further because of warm wet winters and springs, to which it is very sensitive [38].

\section{Ecological models serving climate change studies}

We give a short list of the most widely applied ecological models focused to insect populations.

The Forest Vegetation Simulator (FVS) is a distance-independent, geographic region dependent individual-tree forest growth model that has been widely used in the United States for about 30 years to support management decision making. It has been continuously extended, improved and adapted to further management tasks like prediction of climate change effects. Component models predict the growth and mortality of individual trees, and extensions to the base model represent disturbance agents including insects, pathogens, and fire. The geographic regions are represented by regionally specific model variants. The differences are due to data availability and the applicability of existing models. The model supports specification of management rules in the input [10], [11].

The Phenology and PopulatIoN SIM (INSIM) is an age - structured model that needs biological information on the insect species and gives calculations on the number of individuals and the development of the population. It involves a complex pest - natural enemies model, as well [41], [42].

Agro - ECOsystem ManagemenT and OPtimization Model (ECOTOPE) is a typical simulation model, which describes processes of an agricultural ecosystem for crop growth, nitrogen dynamics in soil and pest population. It is used to derive optimum management strategies [49], [50], [51].

Boundary LAYER Model (BLAYER) simulates atmospheric flows and it has been adapted to forecast the timing and location of insect pest migrations into the United States corn belt. It is very useful to study the possible changes in pest populations like migration or dispersal patterns resulted by climate change [45].

Boll Weevil DISPersal Model (BWDISP) is a stochastic simulation model that predicts the spread of boll weevil populations on cotton. Because the development and dispersal of this insect is sensitive to temperature, it is important to understand how this insect will potentially respond to climate change. In addition, without proper management of this pest, other secondary pests may attack the crop [40]. 
Northern Corn ROOTWORM Model (ROOTWORM) is a process-oriented simulation model that examines the population dynamics of corn-rootworm in the northern United States. The rootworm attacks both the roots and tassels of corn, decreasing yields. The model examines how planting date affects the population dynamics of the insects. It gives information on phenology and the number of individuals in each growth state of corn. The model can analyze global change impact on the population levels and distribution of the insects, as well as the potential economic impacts [43].

\section{The potential responses of insects to climate change}

Climate and weather can substantially influence the development and distribution of insects. Current estimates of changes in climate indicate an increase in global mean annual temperatures of $1^{\circ} \mathrm{C}$ by 2025 and $3^{\circ} \mathrm{C}$ by the end of the next century. Such increases in temperature have a number of implications for temperature-dependent insects, especially in the region of Middle - Europe. Changes in climate may result changes in geographical distribution, increased overwintering, changes in population growth rates, increases in the number of generations, extension of the development season, changes in crop-pest synchrony of phenology, changes in interspecific interactions and increased risk of invasion by migrant pests.

Under the climatic changes projected by the Goddard Institute for Space Studies general circulation model, northward shifts in the potential distribution of the European corn borer of up to $1220 \mathrm{~km}$ are estimated to occur, with an additional generation found in nearly all regions where it is currently known to occur [46].

Several results on the effect of climate change on insects were published in the field of forestry sciences, since insects cause considerable loss of wood that has an adverse effect on the balance of carbon sequestered by forests. Volney and Fleming [56] state that pests are major, but consistently overlooked forest ecosystem components that have manifold consequences to the structure and functions of future forests. Global change will have demonstrable changes in the frequency and intensity of pest outbreaks, particularly at the margins of host ranges.

Ayres and Lombardero [2] have shown that climate change has

- direct effects on the development and survival of herbivores and pathogens;

- physiological changes in tree defenses; and

- indirect effects from changes in the abundance of natural enemies (e.g. parasitoids of insect herbivores), mutualists (e.g. insect vectors of tree pathogens), and competitors.

Because of the short life cycles of insects, mobility, reproductive potential, and physiological sensitivity to temperature, even modest climate change will have rapid impacts on the distribution and abundance of many kinds of insects. To consider scenario studies, some of them predict negative, but many forecast positive effects on insects. E.g. global warming accelerates insect development rate and facilitate range expansions of pests, moreover, climate change tends to increase the vulnerability of plants to herbivores. One alarming scenario is that climate warming may increase insect outbreaks in boreal forests, which would tend to increase forest fires and exacerbate further climate warming by releasing carbon stores from boreal ecosystems [2].

Hanson and Weltzin [19] studied especially the drought disturbances caused by climate change. They showed that severe or prolonged drought may render trees more susceptible to insects. 
Climate variability at decadal scales influences the timing and severity of insect outbreaks that may alter species distributions. Coops and al. [9] have presented a spatial modelling technique to infer how a sustained change in climate might alter the geographic distribution of the species. Using simulations they produced a series of maps that display predicted shifts of zones where the species they examined might expand its range if modelled climatic conditions at annual and decadal intervals were sustained.

The connection between temperature tolerance and phenology of insects was investigated by Klok and Chown [25]. They defined how current climate change like increased temperature and decreased rainfall affect on physiological regulation and susceptibility.

Powell and Logan [47] have reviewed the mathematical relationship between environmental temperatures and developmental timing and analyzed circle maps from yearly oviposition dates and temperatures to oviposition dates for subsequent generations. Applying scenarios for global warming they proved that adaptive seasonality may break down with little warning with constantly increasing (and also decreasing) temperature.

Forecasted increases in atmospheric $\mathrm{CO}_{2}$ and global mean temperature are likely to influence insect - plant interactions. Plant traits important to insect herbivores, such as nitrogen content, may be directly affected by elevated $\mathrm{CO}_{2}$ and temperature, while insect herbivores are likely to be directly affected only by temperature. Flynn et al. [14] stated that insect populations did not change significantly under elevated $\mathrm{CO}_{2}$, but tended to increase slightly. Average weight decreased at high temperatures. Plant height and biomass were not significantly affected by the $\mathrm{CO}_{2}$ treatment, but growth rates before infestation were enhanced by elevated $\mathrm{CO}_{2}$. These results indicate that the combined effects of both elevated $\mathrm{CO}_{2}$ and temperature may exacerbate pest damage to certain plants, particularly to plants which respond weakly to increases in atmospheric $\mathrm{CO}_{2}$.

Up to this time, as we have seen, mainly two climatic factors - temperature and humidity have been investigated. Though, it is possible that some parts of solar radiation have at least the same importance in controlling insect populations [6].

Last, but not least, changes in climate increases the likelihood of insect transport from regions to regions, as well $[22,23,55,57]$.

\section{The special agricultural aspects of climate change effect on insects}

Global climate change impact on plant - pest populations depends on the combined effects of climate (temperature, precipitation, humidity) and other components like soil moisture, atmospheric $\mathrm{CO}_{2}$ and tropospheric ozone $\left(\mathrm{O}_{3}\right)$. Changes in agricultural productivity can be the result of direct effects of these factors at the plant level, or indirect effects at the system level, for instance, through shifts in insect pest occurrence. With respect to crops, the data suggest that elevated $\mathrm{CO}_{2}$ may have many positive effects, including yield stimulation, improved resource - use efficiency, more successful competition with weeds, reduced $\mathrm{O}_{3}$-toxicity, and in some cases better pest and disease resistance. However, many of these beneficial effects may be lost - at least to some extent - in a warmer climate. Warming accelerates plant development and reduces grain-fill, reduces nutrient-use efficiency, increases crop water consumption, and favours weeds over crops. Also, the rate of development of insects may be increased. A major effect of climate warming in the temperate zone could be a change in winter survival of insect pests, whereas at more northern latitudes shifts in phenology in terms 
of growth and reproduction, may be of special importance. However, climate warming disturbs the synchrony between temperature and photoperiod; because insect and host plant species show individualistic responses to temperature, $\mathrm{CO}_{2}$ and photoperiod, it is expected that climate change will affect the temporal and spatial association between species interacting at different trophic levels. Although predictions are difficult, it seems reasonable to assume that agro-ecosystem responses will be dominated by those caused directly or indirectly by shifts in climate, associated with altered weather patterns, and not by elevated $\mathrm{CO}_{2}$ per se. Overall, intensive agriculture may have the potential to adapt to changing conditions, in contrast to extensive agricultural systems or low - input systems which may be affected more seriously [18].

Crop protection in Europe became strongly chemically oriented in the middle of the last century. An excellent climate for fast reproduction of pests and diseases demanded high spray frequencies and, thus, resulted in quick development of resistance against pesticides. This initiated a search for alternatives of chemical pesticides, like natural enemies for control of pests. A change from chemical control to very advanced integrated pest management programs (IPM) in European greenhouses took place at the end of the last century [38]. For the main greenhouse vegetable crops in northern Europe, most insect problems can now be solved without the use of insecticides. IPM without conventional chemical pesticides is a goal that will be realized for most of the important vegetables in Europe, not limited to greenhouse vegetables. At the same time, however, climate change affects the distribution, the phenology, the susceptibility and the interrelationship of insects drastically, which emphasize the risk of sustainable crop protection by loosing the control on pests - natural enemies' populations.

\section{Materials and Methods}

\section{The methods of modelling}

In a former work [33] we have introduced a food web population dynamical model that describes the biomass change of the members of a food web with a cultivated plant and two kinds of weed, monophagous and polyphagous pests and a predator. In what follows, we apply this model for our Corythuca ciliata - Sycamore tree population with three purposes:

- we show, how the model works in practise

- we find out the model-parameters for a Corythuca ciliata - Sycamore tree population and

- with the help of the food web population dynamical model, we try to get information out of weather parameters for plant protection purposes.

The examined Corythuca ciliata - Sycamore tree population shows a very simple case of the general food web seasonal population dynamical model:

- Though there exist several natural enemies of Sycamore lace bug, under natural circumstances they do not appear at all in Hungary, or they are playing no limiting role in reproduction. Thus, we consider Sycamore lace bug in the model, as a pest of Sycamore tree having no predator.

- Though the rate of Sycamore lace bug infection can be quite high in Hungary, the size of the population has never been limited by the Sycamore tree population. Thus, we assume in the model, that there is no nutrient limitation of Sycamore lace bug. 
- Sycamore lace bug is monophagous and nowadays it is the most important pest of Sycamore trees.

To simulate the population of Sycamore lace bug, we used a model with discretetime (with daily scale), deterministic and weather-dependent difference equations.

The model has a format of MS Excel so that it can widely be applied. The parameters of the model were fitted to the empirical data with the help of MS Excel Solver. The empirical data were gathered between 1989 and 1999 in public parks of Budapest, Hungary [44].

\section{Results}

\section{General biomass model}

Our drastically simplified food web biomass seasonal population dynamical model applied for the examined Corythuca ciliata - Sycamore tree population is generally as follows:

$$
M_{t+1}=M_{t} \cdot R_{t}
$$

where

the amounts of the biomass of Sycamore lace bug population at the $(t+1)^{\text {th }}$ and at the $t^{\text {th }}$ points of time are denoted by $M_{t+1}$ and $M_{t}$, respectively

the activity term of the entities of $M$ is denoted by $R_{t}$ is depending on the daily average temperature $T$.

In what follows the terms of the general equation are introduced.

\section{The activity term $R_{t}$ and the cumulated activity $\underset{t \geq t_{s}}{c u m} R_{t}^{P h}$}

Activity term $R_{t}$ expresses that the agro-ecological process - that was represented by the general biomass model above - is depending on the daily average temperature; nevertheless, the effect of the same temperature on the entities can be different in different phenological phases (Table 1 and 2).

Let us denote by $t_{s}$ the so-called 'first spring day of the population' and by $t_{w}$ the 'first winter day of it'. We say, that the vegetation period of a population lies between $t_{s}$ and $t_{w}$.

The cumulated activity is defined by

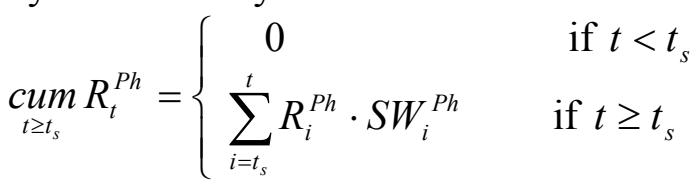

Cumulated activity $\operatorname{cum}_{t \geq t_{s}} R_{t}^{P h}$ cumulates the values of activity terms $R_{t}$ of Sycamore lace bug from a starting point of time, $t_{s}$ (from 'the first spring day of Sycamore lace bug'), in the case phase $P h$ holds. $P h$ denotes one of $L_{i j}$ (for the $j^{\text {th }}$ larva state of the $i^{\text {th }}$ generation, $i=1,2, j=1,2, \ldots, 5$ ) and $I_{i}$ (for the imago state of the $i^{\text {th }}$ generation $i=1,2,3$ ).

Cumulated activity $\operatorname{cum}_{t \geq t_{s}} R_{t}^{P h}$ of Sycamore lace bug is calculated with the help of a characteristic function $S W_{t}^{P h}$ : 
where

$$
S W_{t}^{P h}= \begin{cases}0 & \text { if } t=0 \text { and } P h>I_{1} \\ \prod_{P h>I_{1}}\left(1-S W_{t}^{\underline{P h}}\right) & \text { if } P h=I_{1} \\ \min \left[\max \left\{\left(C u m R_{t}^{P h}-T_{m}^{P h}\right), 0\right\}, 1\right] \prod_{\underline{P h}>P h}\left(1-S W_{t}^{\underline{P h}}\right) & \text { if } t>0 \text { and } P h>I_{1}\end{cases}
$$

$T_{m}^{P h} \quad$ denotes the minimum of cumulated activity of Sycamore lace bug $\operatorname{cum}_{t \geq t_{s}} R_{t}^{P h}$ that is necessary to enter phase $P h$

and relation $\underline{P h}>P h$ means that, for all phases later than phase $P h \quad$ ".

For a fixed point of time $t$ and a phenophase $P h, S W_{t}^{P h}$ shows, whether the phase $P h$ holds at a point of time $t$, that is to say:

(Figures 1, 2, 3 and 4)

$$
S W_{t}^{P h}= \begin{cases}0 & \text { if } P h \text { holds } \\ 1 & \text { if } P h \text { does not hold }\end{cases}
$$

Table 1. The values of activity term $R_{t}$ of the daily average temperature T. Activity term expresses that the agro-ecological process $M_{t+1}=M_{t} \cdot R_{t}$ is depending on the daily average temperature differently in different phenophases.

\begin{tabular}{|c|c|c|}
\hline & Conditions & $R_{t}$ \\
\hline Earlier than the first spring day & $t<t_{s}$ & 0.90 \\
\hline \multirow{3}{*}{ In the third Imago phase } & $22<\operatorname{cum}_{t} R_{t-1}^{I_{3}}<33$ & 0.90 \\
\cline { 2 - 3 } & $\operatorname{cum}_{t} R_{t-1}^{I_{3}}>33$ & 1 \\
\hline \multirow{4}{*}{ Else } & $T<5$ & 0.98 \\
\cline { 2 - 3 } & $5 \leq T<10$ & 0.99 \\
\cline { 2 - 3 } & $10 \leq T<15$ & 1.06 \\
\cline { 2 - 3 } & $15 \leq T<21$ & 1.08 \\
\cline { 2 - 3 } & $21 \leq T<26$ & 1.04 \\
\cline { 2 - 3 } & $26 \leq T$ & 0.80 \\
\hline
\end{tabular}




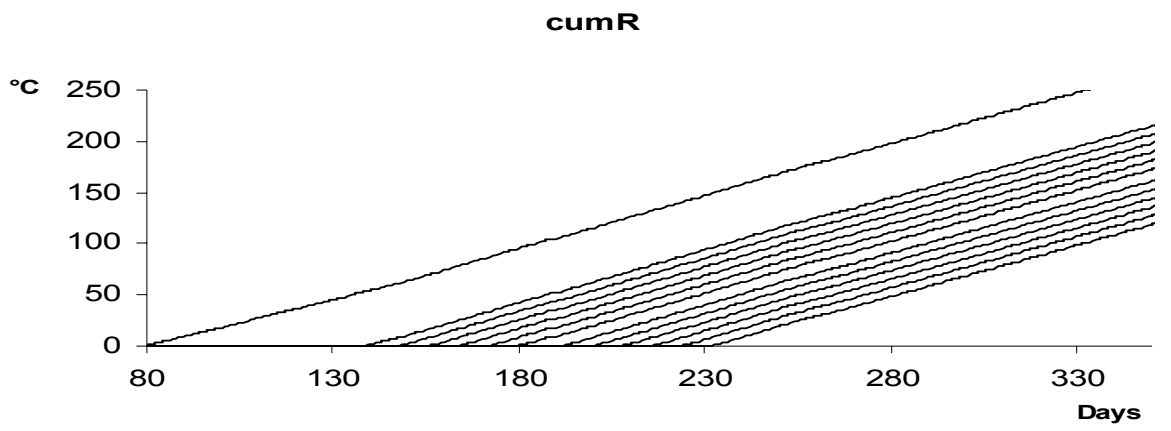

Figure 1. The graphs of cumulated activities $\underset{t \geq t_{s, M}}{\operatorname{cum}} R_{t}^{P h}$ for $P h=I_{1}, L_{11}, L_{12}, L_{13}, L_{14}, L_{15}$ as well as for $P h=I_{2}, L_{21}, L_{22}, L_{23}, L_{24}, L_{25}, I_{3 . .} \operatorname{cum}_{t \geq t_{s}} R_{t}^{P h}$ cumulates the values of activity terms $R_{t}$ of Sycamore lace bug from a starting point of time, $t_{s}$.

Note that though the graphs of $\underset{t \geq t_{s, M}}{c u m} R_{t}^{P h}$ seem to be straight lines, it is not the fact.

cumR_magnified_1

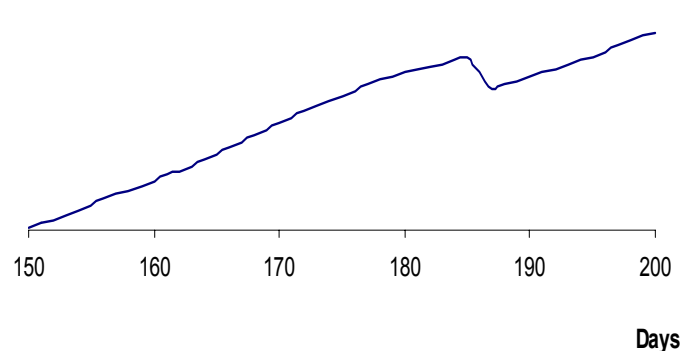

cum R_magnified_2

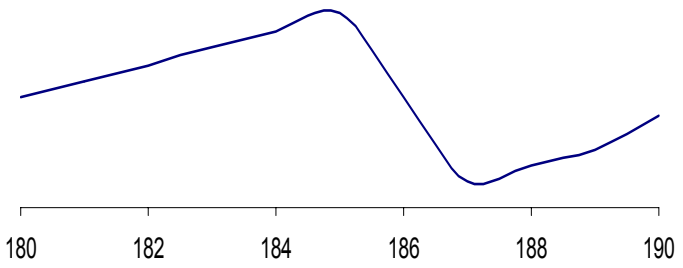

Days

Figure 2. The graphs of cumulated activities $\underset{t \geq t_{s, M}}{c u m} R_{t}^{P h}$ seem to be straight lines, it is not the fact. Their lines brake several times.

First, we assume that the phenophases of the population are disjunctive, that is to say each entity of the population belongs to an only phase $P h$. (Later we omit this condition.) Function $S W_{t}^{P h}$ equals to 1 if and only if the Sycamore lace bug population has more than zero number of entities in phase $P h$ at a given point of time $t$, and equals to 0 , else. The change of the values of function $S W_{t}^{P h}$

- from 0 to 1 is caused by the fact cumulated activity $\underset{t \geq t_{s}}{c u m} R_{t}^{P h}$ has reached the minimum that is necessary for the entities to enter phase $P h+1$, that is to say $\operatorname{cum}_{t \geq t_{s}} R_{t}^{P h}>T_{m}^{P h}$.

- from 1 to 0 is caused by the fact the next phase has been entered. 
Characteristic functions $\operatorname{SW}(P h, t)$

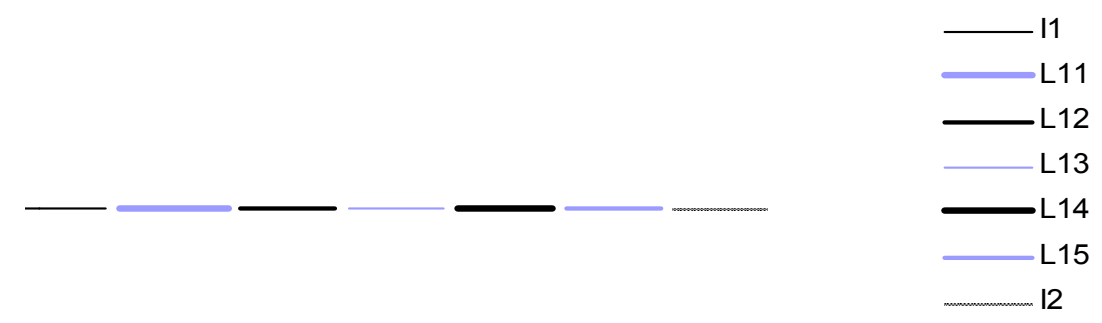

Figure 3. The graphs of characteristic functions $S W_{t}^{P h}$ for $P h=I_{1}, L_{11}, L_{12}, L_{13}, L_{14}, L_{15}$, and $I_{2}$

\section{Characteristic functions $\operatorname{SW}(P h, t)$}

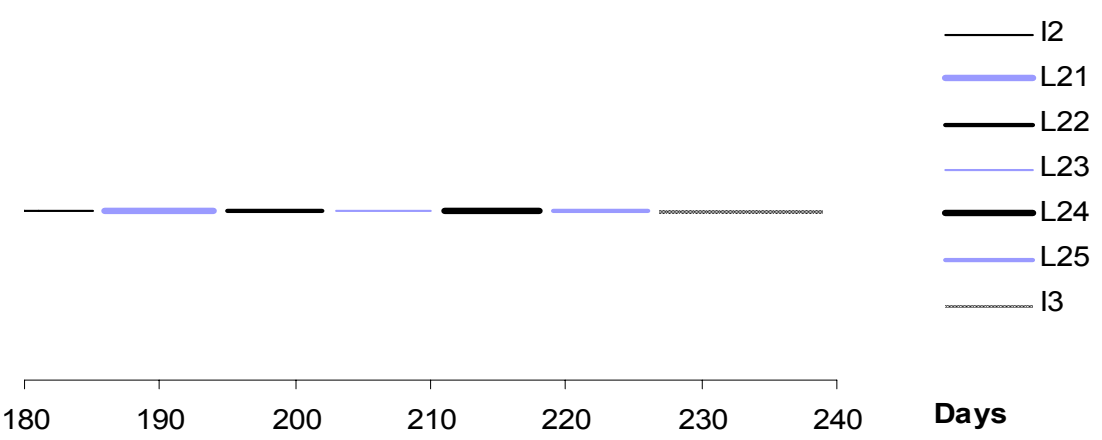

Figure 4. The graphs of characteristic functions $S W_{t}^{P h}$ for $P h=I_{2}, L_{21}, L_{22}, L_{23}, L_{24}, L_{25}$, and $I_{3}$

\section{The smoothed characteristic function $S S W_{t}^{P h}$}

Our main aim is to define the current number of the entities if we know the current biomass of Sycamore lace bug. On the way to our goal we have to keep in mind that there is a point of time a phase is entered first, and there is another one at which the process of metamorphosis is finished for the whole population. This means that there can usually appear more than one phenological phases at the same time (as opposed to our earlier assumption). Thus, function $S W_{t}^{P h}$ that 'switches' on/off the phases has to be 'smoothed' in order to get the number of entities later more exactly. The smoothed characteristic function $S S W_{t}^{P h}$ is defined as follows:

At $t=0$, we have $S S W_{t}^{I_{1}}=1$ and $S S W_{t}^{P h}=0$ for all phases $P h>I_{1}$. (At the beginning of spring there are entities in the first Imago phase, only.) At the point of time the minimal value of cumulated activity $\operatorname{cum}_{t} R_{t}^{P h-1}$, that is necessary to enter phase $P h$ (denoted by $T_{m}^{P h-1}$, see Table 2), has been exceeded ( $\underset{t}{\operatorname{cum}} R_{t}^{P h-1}>T_{m}^{P h-1}$ ), the entities of phase $P h-1$ are starting to enter phase $P h$. (We say, that at the point of time $t$, when ${ }_{t}^{c u m} R_{t}^{P h-1}>T_{m}^{P h-1}$ first, phase $P h$ is entered first.) During the time of metamorphosis 
from $P h-1$ to $P h$, the value of $S S W_{t}^{P h}$ is growing from zero to 1 (though, it is not necessary that $S S W_{t}^{P h}$ reaches 1 , indeed. We can say only that $\left.0 \leq S S W_{t}^{P h} \leq 1\right)$. The value of $S S W_{t}^{P h}$ reaches its potential maximum (pot $\left.\max S S W_{t}^{P h}=1\right)$, if cum $R_{t}^{P h-1}>T_{M}^{P h-1}$ and if $\operatorname{cum}_{t} R_{t}^{P h}<T_{m}^{P h}$, that is to say, the metamorphosis to the next phase, $P h+1$ has still not began. (At this point of time the process of metamorphosis from $P h-1$ to $P h$ is finished for the whole population.) In the case the minimal value of cumulated activity $\operatorname{cum}_{t} R_{t}^{P h}$, that is necessary to enter phase $P h+1$ (denoted by $T_{m}^{P h}$ ), has been exceeded ( $c u m R_{t}^{P h}>T_{m}^{P h}$ ), then $S S W_{t}^{P h}$ starts to decrease monotonously to zero.

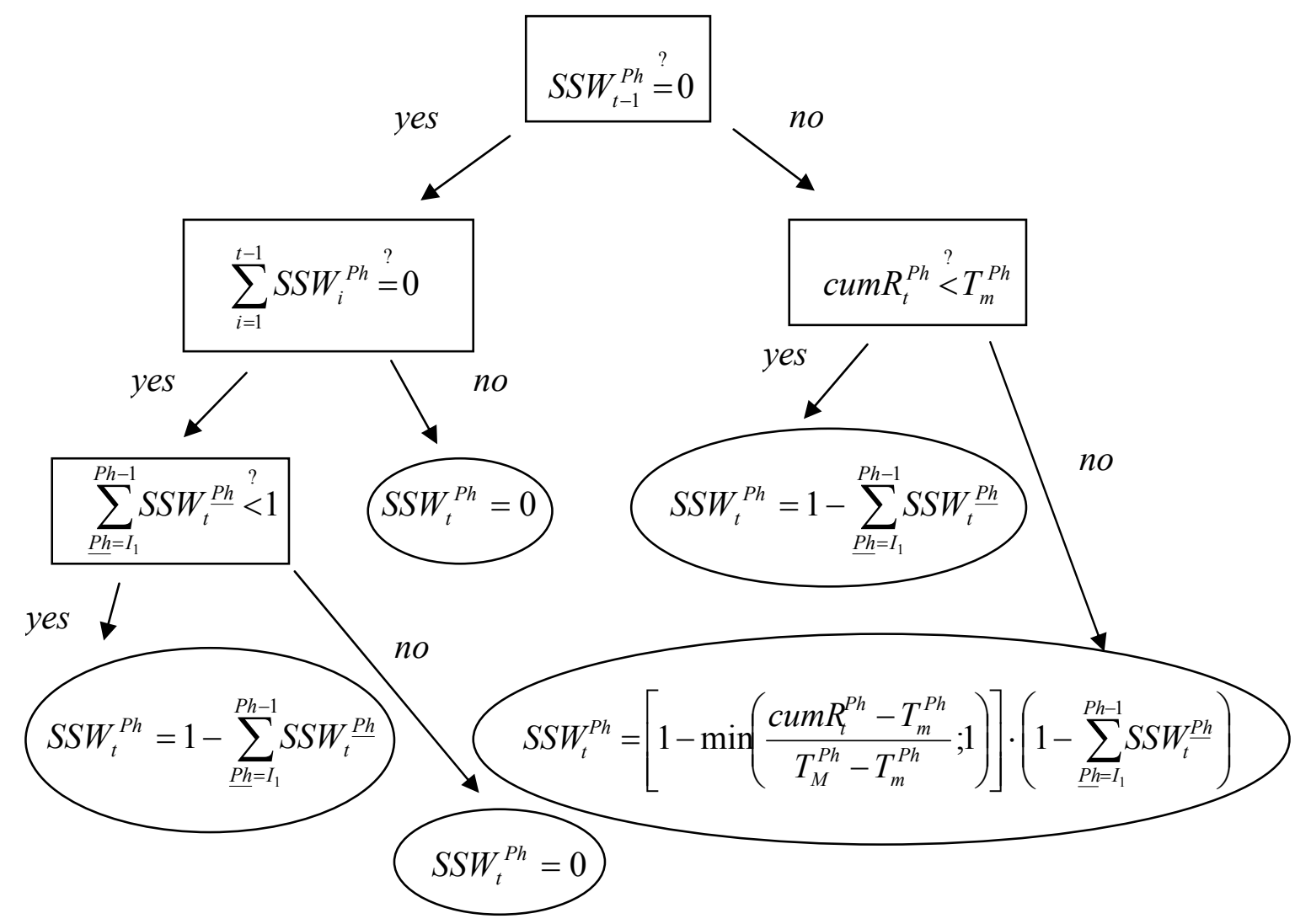

Figure 5. The way of evaluation of function $S S W_{t}^{P h}$. Considering that the metamorphosis from phase Ph to phase Ph +1 is a continuous process, characteristic function $S W_{t}^{P h}$ that 'switches' on/off the phases has to be smoothed in order to get the number of entities later more exactly.

(For $P h=I_{1}$ we say that $S S W_{t}^{P h-1}=0$ for each $t$.)

If $\operatorname{cum}_{t} R_{t}^{P h}>T_{m}^{P h}$ at the point of time $t$ when $\operatorname{cum}_{t}^{P h-1}>T_{M}^{P h-1}$ first, then $S S W_{t}^{P h}$ cannot reach its potential maximum value $\left(\max S S W_{t}^{P h}<\operatorname{pot} \max S S W_{t}^{P h}=1\right)$, because the metamorphosis from $P h-1$ to $P h$ ends later than the metamorphosis from $P h$ to $P h+1$ starts. 
At the point of time at which the whole process of metamorphosis from $P h$ to $P h+1$ is finished, namely, when ${ }_{t} u m R_{t}^{P h}>T_{M}^{P h}$, the value of $S S W_{t}^{P h}$ becomes to be equal to, and keeps to be, zero (Figures 5, 6 and 7).

It is easy to see that $\sum_{\text {for all phases } P h} S S W_{t}^{P h}=1$.

Table 2. The values of $T_{m}^{P h}$ and $T_{M}^{P h}$. At the point of time $t$, when $\underset{t}{\operatorname{cum}} R_{t}^{P h-1}>T_{m}^{P h-1}$ first, phase Ph is entered first. At the point of time cum $R_{t}^{P h-1}>T_{M}^{P h-1}$ first, the process of metamorphosis from $\mathrm{Ph}-1$ to $\mathrm{Ph}$ is finished.

\begin{tabular}{|c|c|c|c|c|c|c|c|c|c|c|c|c|}
\hline Phase & $I_{1}$ & $L_{11}$ & $L_{12}$ & $L_{13}$ & $L_{14}$ & $L_{15}$ & $I_{2}$ & $L_{21}$ & $L_{22}$ & $L_{23}$ & $L_{24}$ & $L_{25}$ \\
\hline$T_{m}^{P h}$ & 52 & 7 & 7 & 7 & 7 & 7 & 7 & 7 & 7 & 7 & 7 & 7 \\
\hline$T_{M}^{P h}$ & 67 & 27 & 32 & 37 & 37 & 37 & 37 & 37 & 42 & 42 & 42 & 42 \\
\hline
\end{tabular}

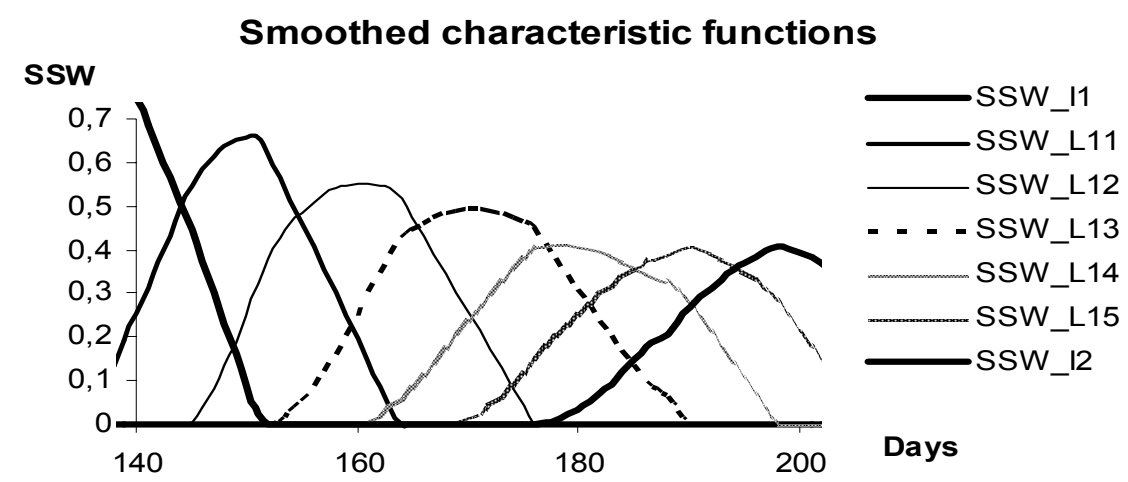

Figure 6. The graphs of smoothed characteristic functions $S S W_{t}^{P h}$ for $P h=I_{1}, L_{11}, L_{12}, L_{13}$, $L_{14}, L_{15}$, and $I_{2}$

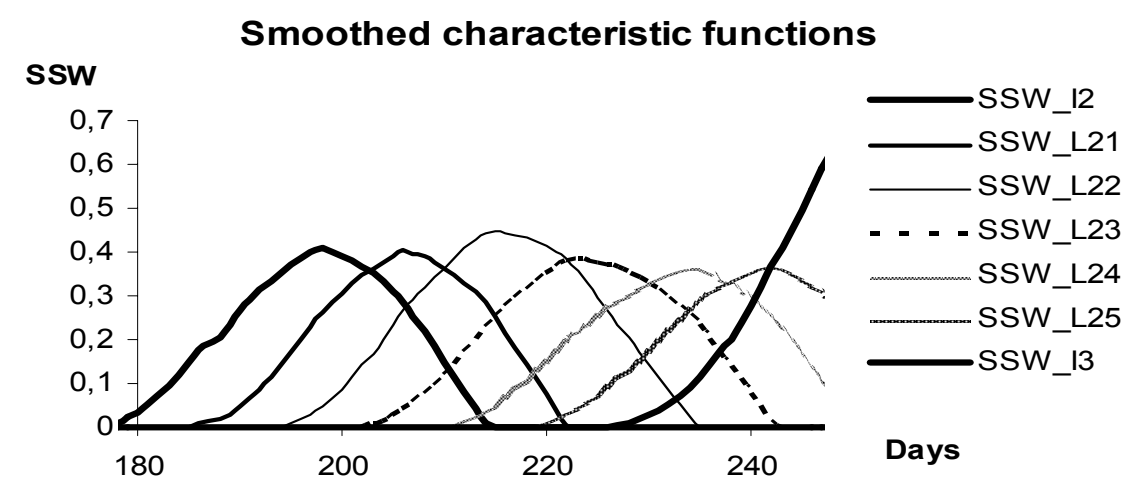

Figure 7. The graphs of smoothed characteristic functions $S S W_{t}^{P h}$ for $P h=I_{2}, L_{21}, L_{22}, L_{23}, L_{24}$, $L_{25}$, and $I_{3}$ 


\section{The number of entities of Sycamore lace bug ( $N o I_{t}^{P h}$ )}

Finally, the numbers of entities of Sycamore lace bug in all phenophases will be calculated as follows. Set out from an estimated value of the number of entities of phase $I_{1}$ at the point of time $t_{0}=0$ :

$$
N o I_{0}^{I_{1}}=\frac{M_{0}}{\bar{m}^{I_{1}}}
$$

where $\bar{m}^{I_{1}}$ denotes the average mass of an only entity of Sycamore lace bug in phenophase $I_{1}$.

The number of entities of Sycamore lace bug for a phenophase $P h$ ) at a point of time $t>0$ is obtained as:

$$
N o I_{t}^{P h}=\left\{\begin{array}{cc}
\min \left(\frac{M_{t}}{m_{t-1}^{P h}} \cdot S S W_{t}^{P h}, \quad k^{P h} \cdot \max _{t \in\{P h-1\}} N o I_{t}^{P h-1}\right) & \text { if } \quad P h \neq L_{i 1} \quad(i=1,2) \\
\frac{M_{t}}{m_{t-1}^{P h}} \cdot S S W_{t}^{P h} & \text { if } \quad P h=L_{i 1} \quad(i=1,2)
\end{array}\right.
$$

where $m_{t}^{P h}$ denotes the current average mass of an only entity of Sycamore lace bug in the phenophase $P h$ at a point of time $t$ :

$$
m_{t}^{P h}=\frac{M_{t}}{N o I_{t}^{P h}}
$$

$t \in\{P h-1\}$ means: "for all $t$ for which $S S W_{t}^{P h-1}>0$ ",

and the multiplier term $k^{P h}$ expresses the standard mortality during the metamorphosis from phase $P h-1$ to phase $P h$ (See Figures 8 and 9).

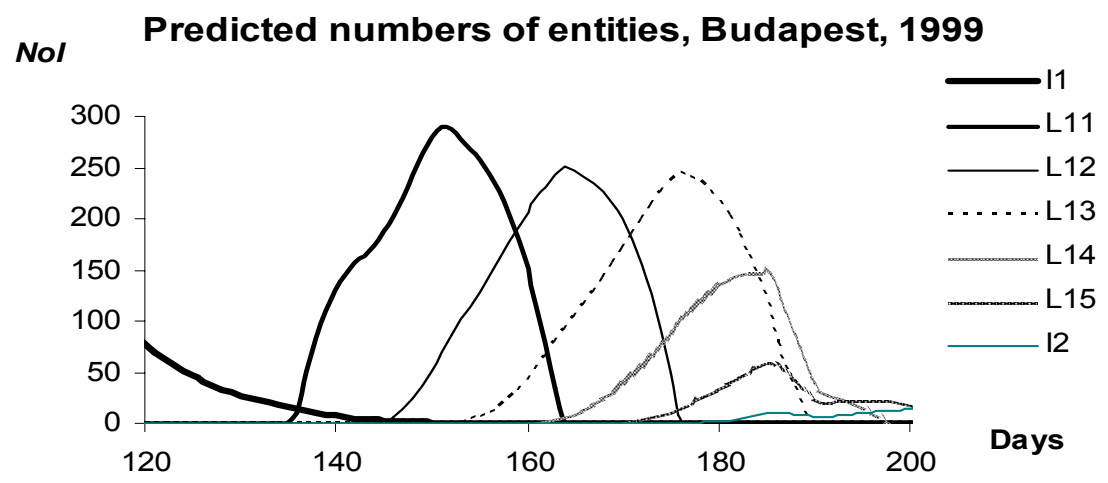

Figure 8. The numbers of Sycamore lace bug entities $\mathrm{NoI}_{t}^{\text {Ph }}$ in Budapest, between the $120^{\text {th }}$ and $200^{\text {th }}$ days of year 1999, predicted by the model for $P h=I_{1}, L_{11}, L_{12}, L_{13}, L_{14}, L_{15}$ and $I_{2}$ 
Nol

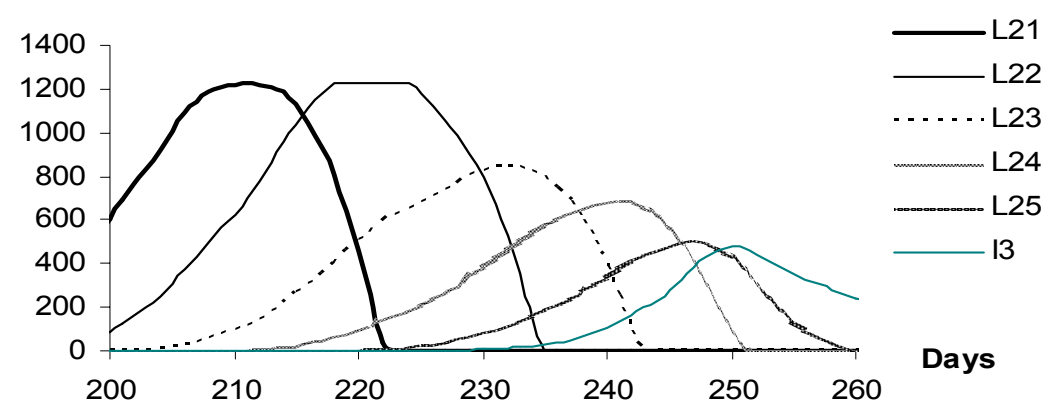

Figure 9. The numbers of Sycamore lace bug entities $\mathrm{NoI}_{t}^{P h}$ in Budapest, between the $200^{\text {th }}$ and $260^{\text {th }}$ days of year 1999, predicted by the model for $P h=L_{21}, L_{22}, L_{23}, L_{24}, L_{25}$, and $I_{3}$

The properties of the function $\mathrm{NoI}_{t}^{P h}$ of the number of entities (of day $t$ ):

1. The sum of the numbers of entities does not increase in any phase except if $P h=L_{i 1}(i=1,2)$, that is to say there is no reproduction except in phases $I_{1}$ and $I_{2}$.

2. During the metamorphosis from a phase $P h$ into the next one (denoted by $P h+1)$, the number of entities in phase $P h$ is decreasing tending to 0 , while the number of entities in phase $P h+1$ is increasing.

3. During the metamorphoses there is a given rate of mortality.

4. The change of the biomass of Sycamore lace bug of phenophase $P h$ can be caused by two facts:

a. the entities are losing/putting on their weights

b. the entities of the population is changing their phase (reproduction or mortality during the metamorphosis)

5. The number of entities does not change in the first case, while in the second one it is decreasing for phenophase $P h$ and increasing for phenophase $P h+1$.

The predictions of the model for the daily number of entities of each phenological phase can be seen in Figures 8 and 9. In order to compare the predictions with the empirical data we displayed the average numbers of entities referred to a leaf (Figure 10). It can be seen that the model follows the empirical data quite well. Its advantage is, however, that it gives such information about each single phenophase that has not been measured. 
Numbers of entities/leaf (empirical data, Budapest, 1999)

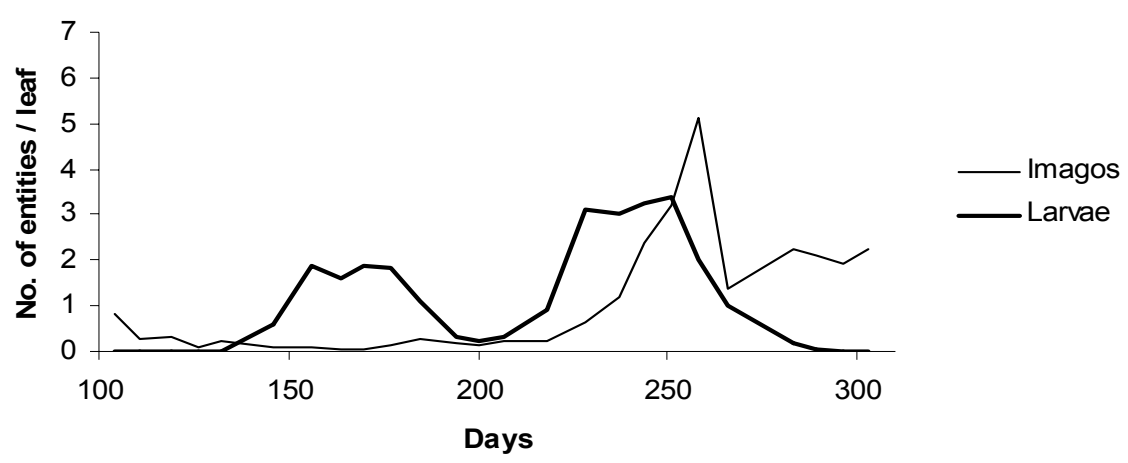

Numbers of entities/leaf (model prediction for Budapest, 1999)

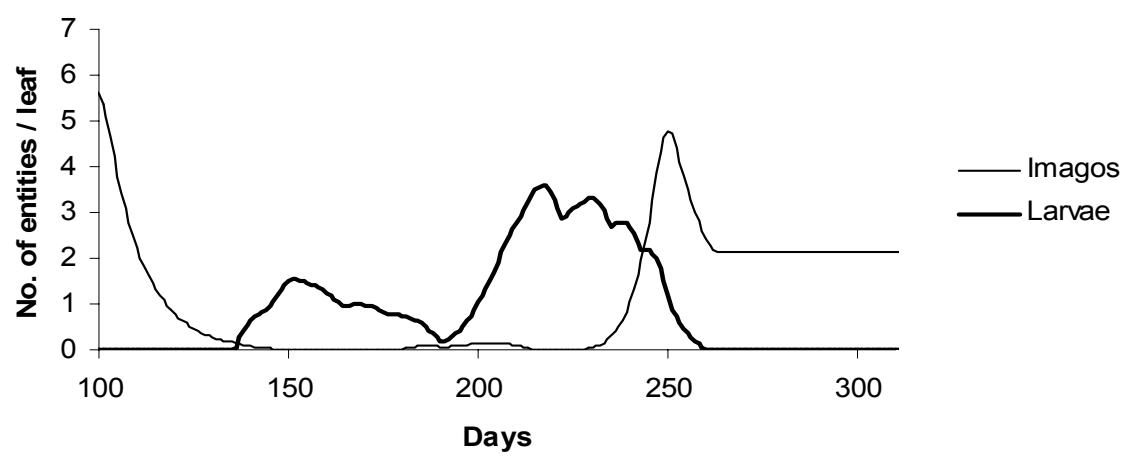

Figure 10. The numbers of Sycamore lace bug imagos and larvae per leaf in Budapest, between the $100^{\text {th }}$ and the $300^{\text {th }}$ days of year 1999

Upper figure: empirical data; Lower figure: model prediction 


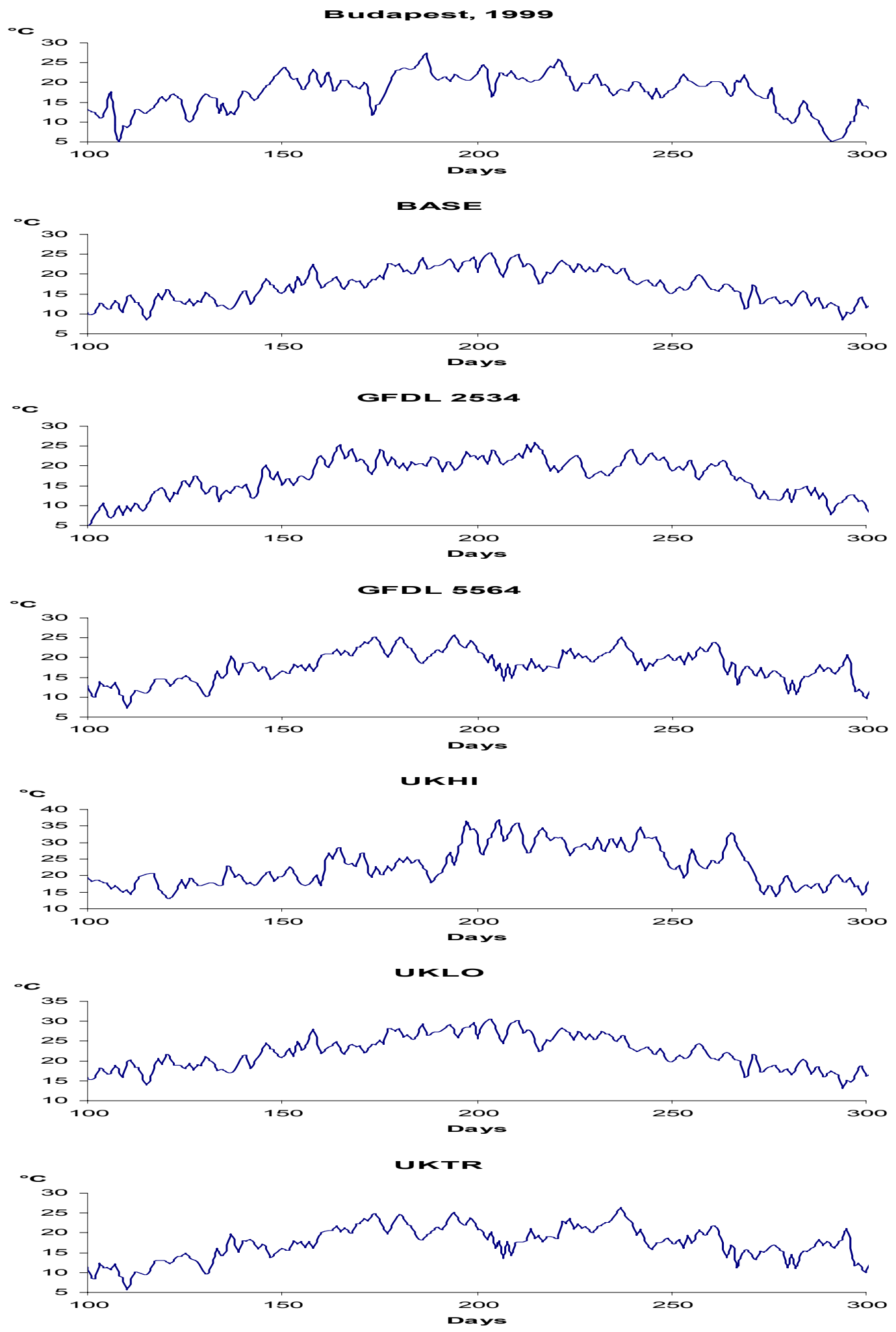

Figure 11. Daily average temperature data of year 1999 and of the $15^{\text {th }}$ years of the scenarios. Note that the scale of axis $y$ of UKLO and UKHI is different because of the essentially higher values. 

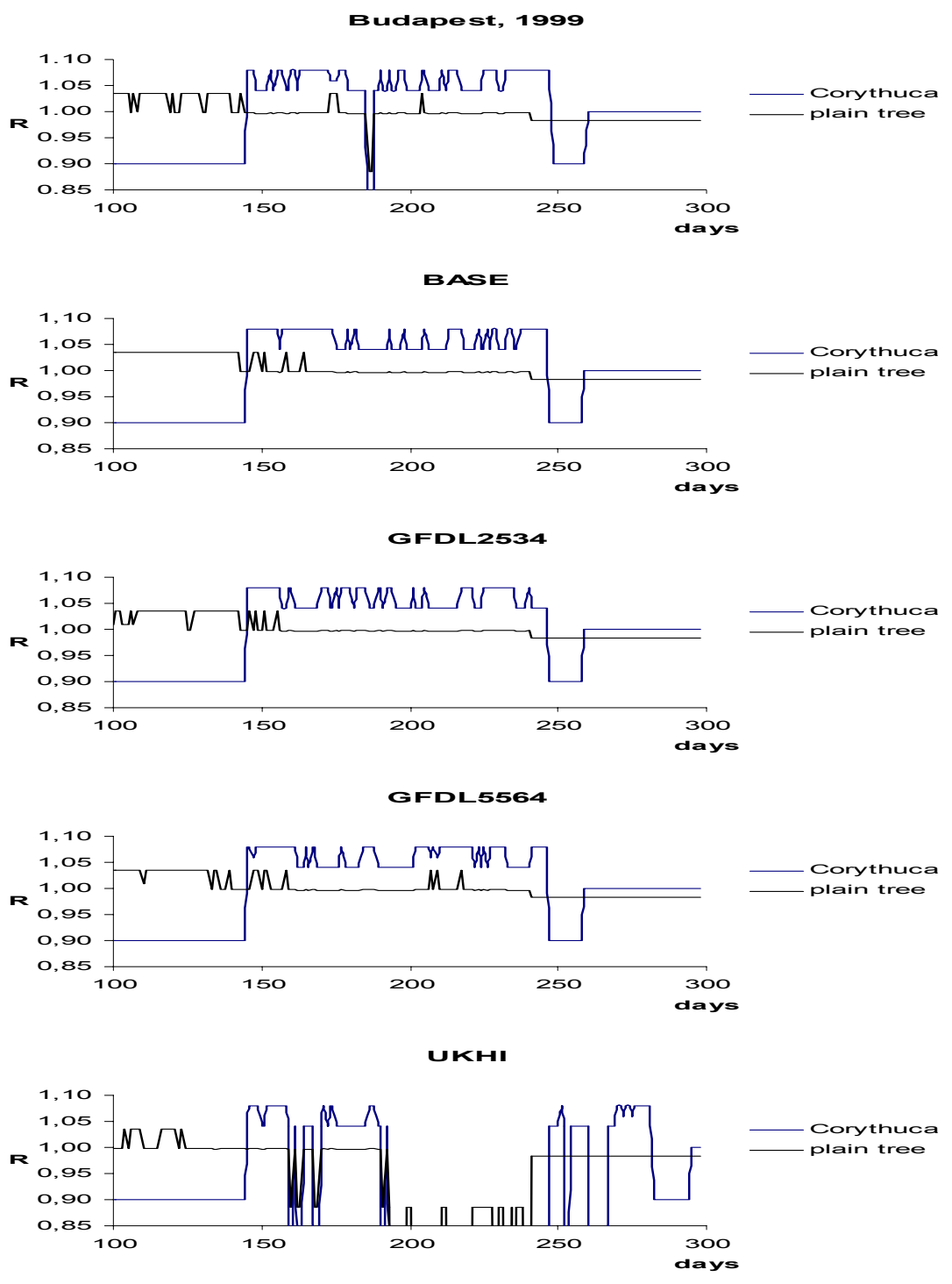

UKLO
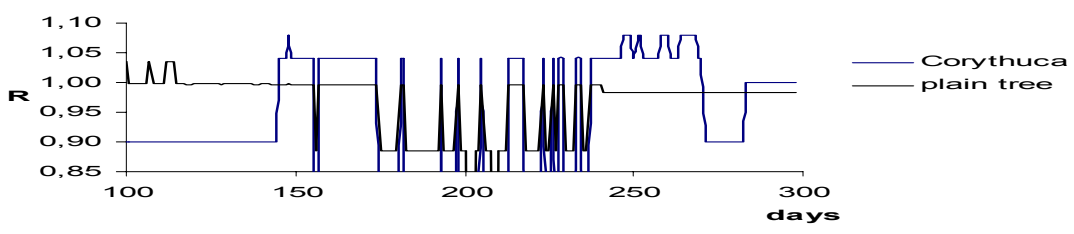

UKTR

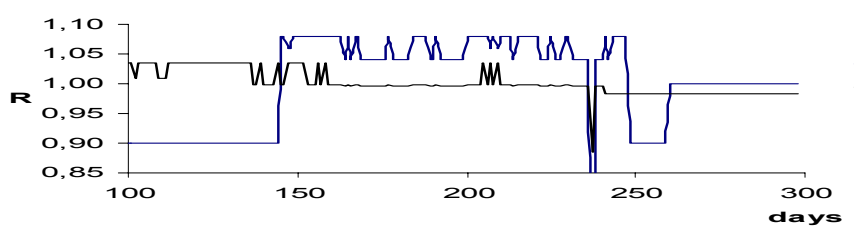

Figure 12. Activity terms $R_{t}$ of the $15^{\text {th }}$ years of the scenarios. In order to see the effect of the climate better, we displayed the activity terms of Corythuca ciliata as well as the ones of Sycamore trees. 
Smoothed characteristic functions, Budapest

SSW

1999

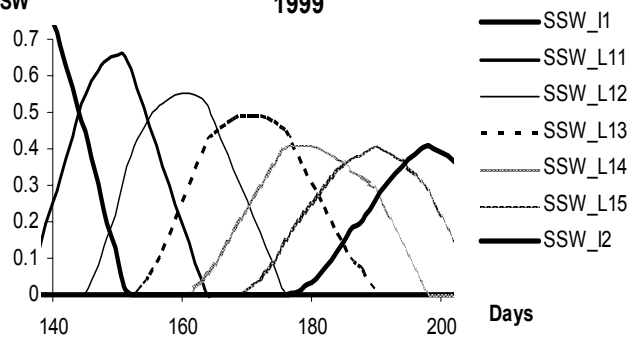

Smoothed characteristic functions, BASE

SsW

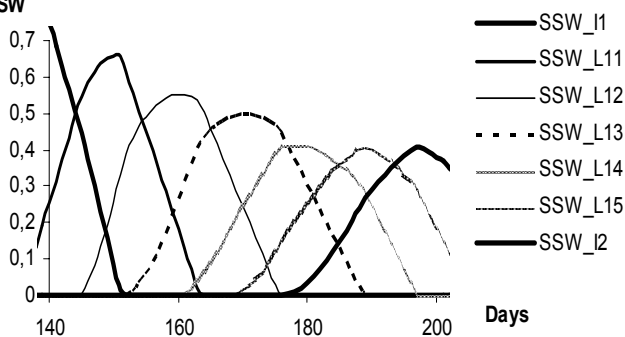

Smoothed characteristic functions, GFDL2534

SSW

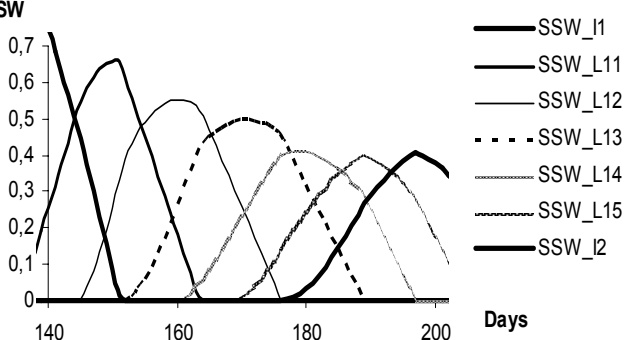

Smoothed characteristic functions, GFDL5564

SSW

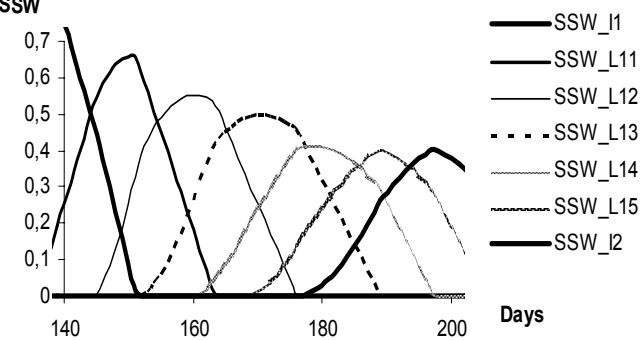

Smoothed characteristic functions, Budapest,

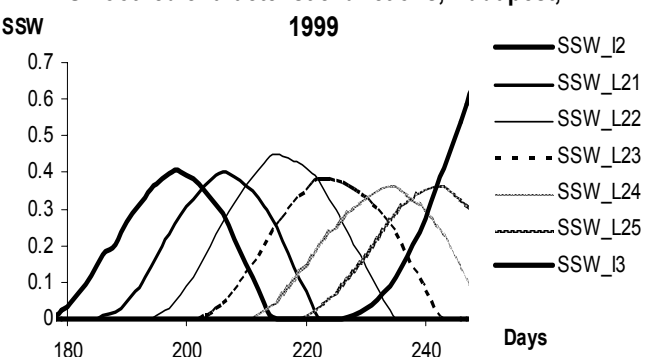

Smoothed characteristic functions, BASE

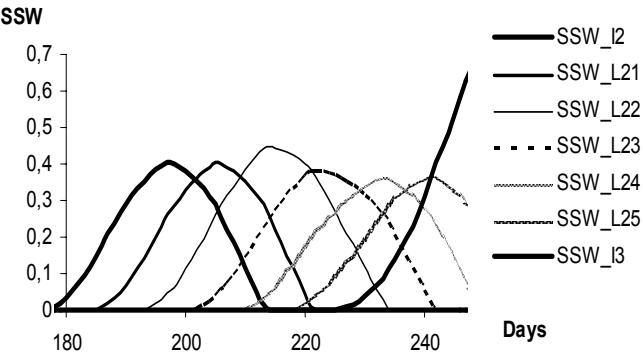

Smoothed characteristic functions, GFDL2534

SSW

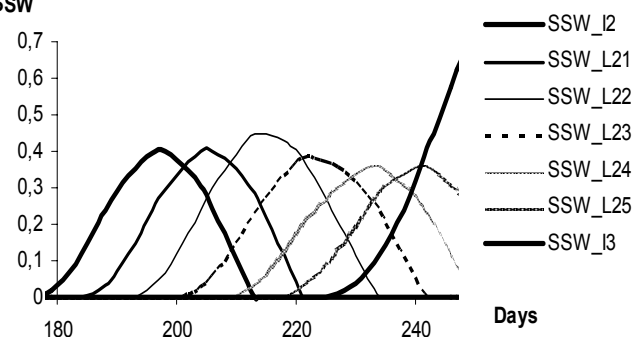

Smoothed characteristic functions, GFDL5564

SSW

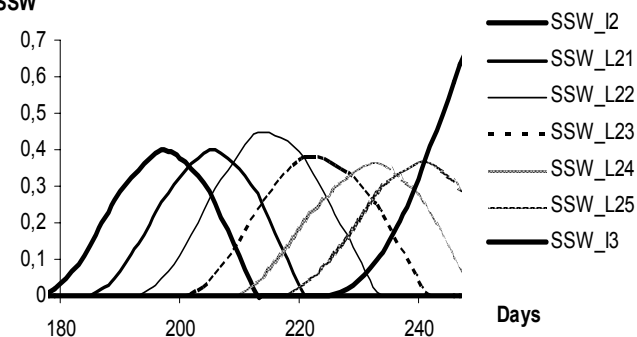



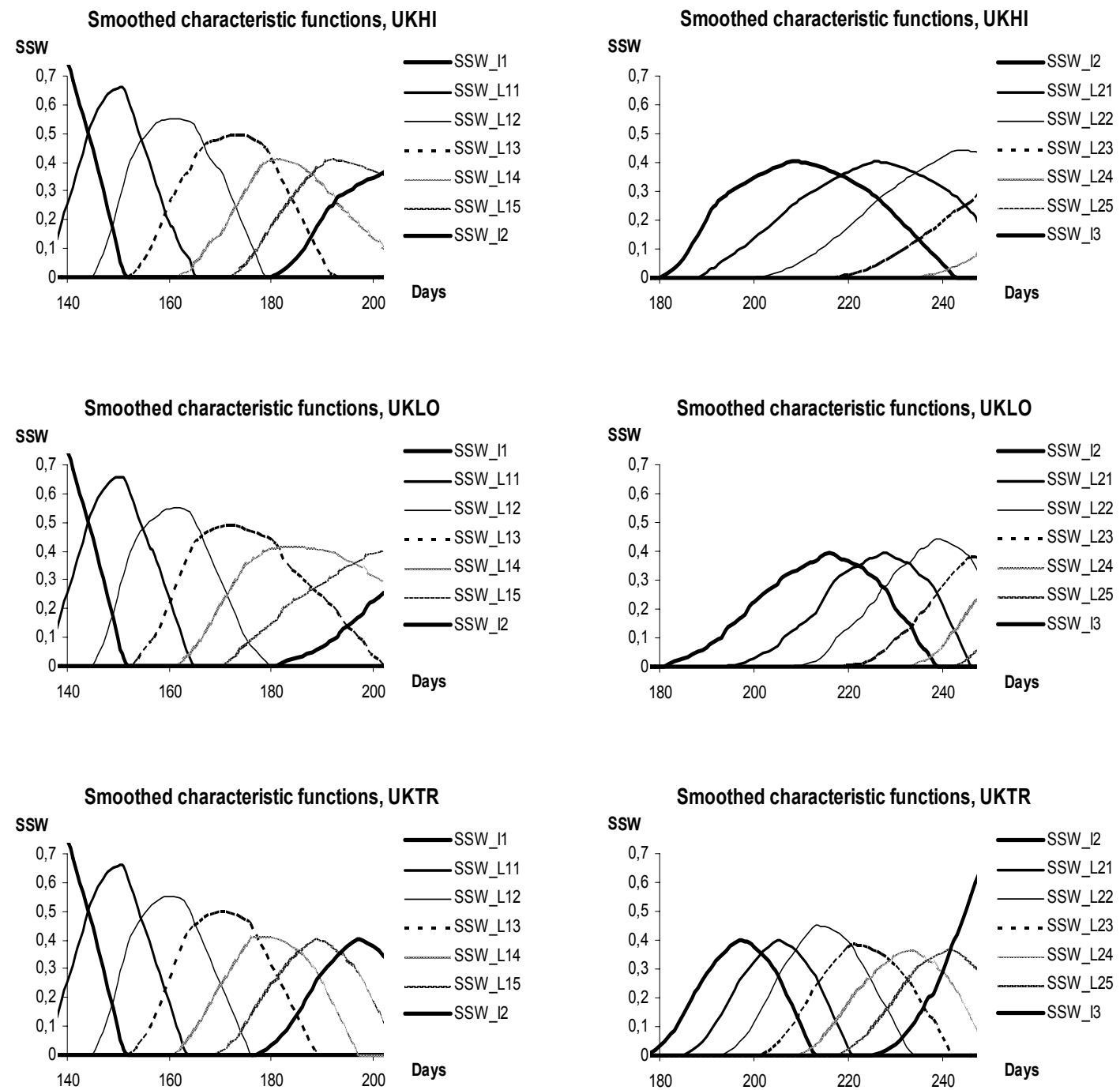

Figure 13. The graphs of smoothed characteristic functions $S S W_{t}^{P h}$ for each phenophase, predicted by the model for Budapest, for 1999 and for the $15^{\text {th }}$ years of the scenarios.
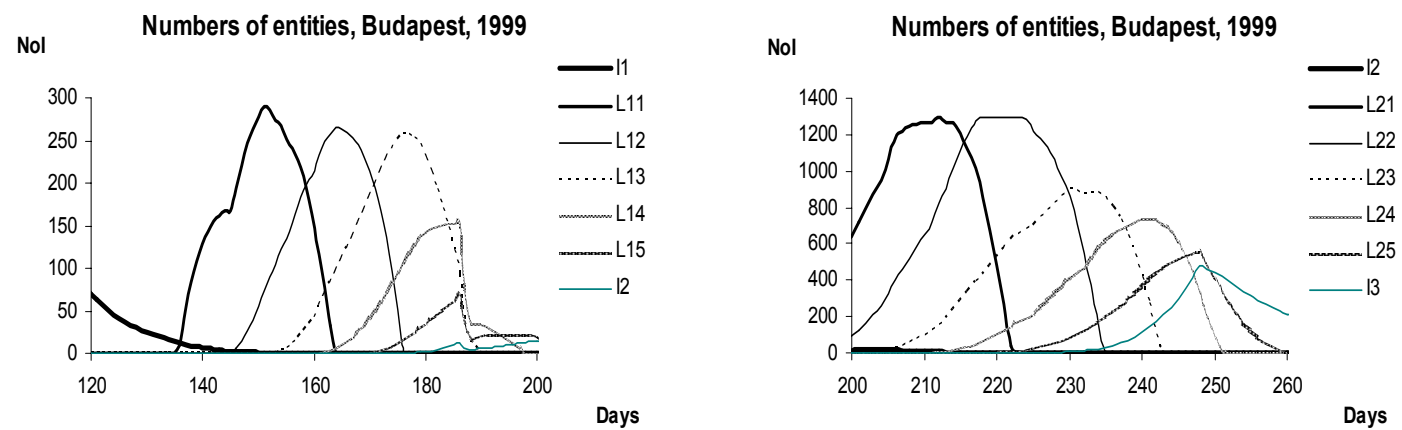

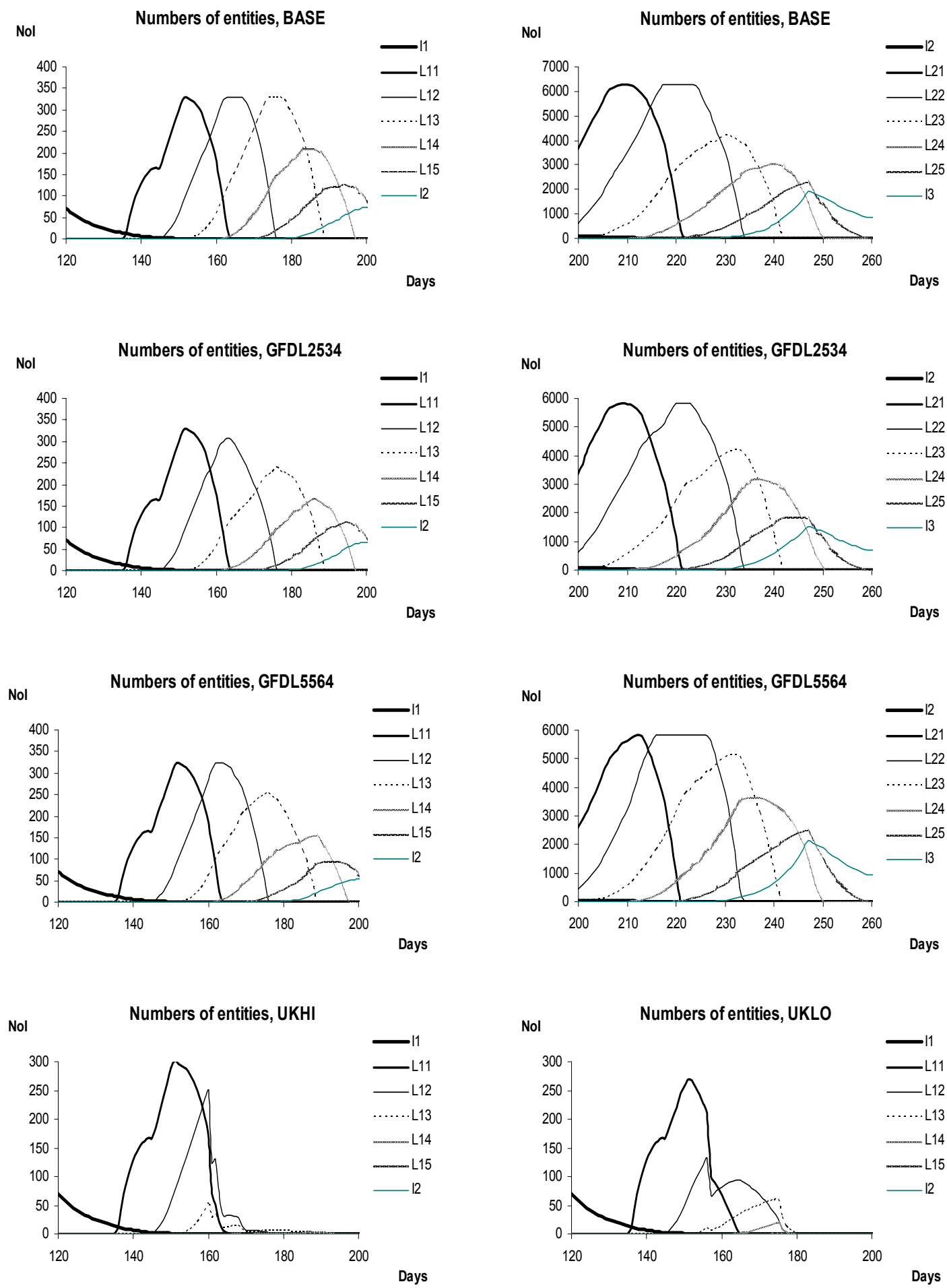

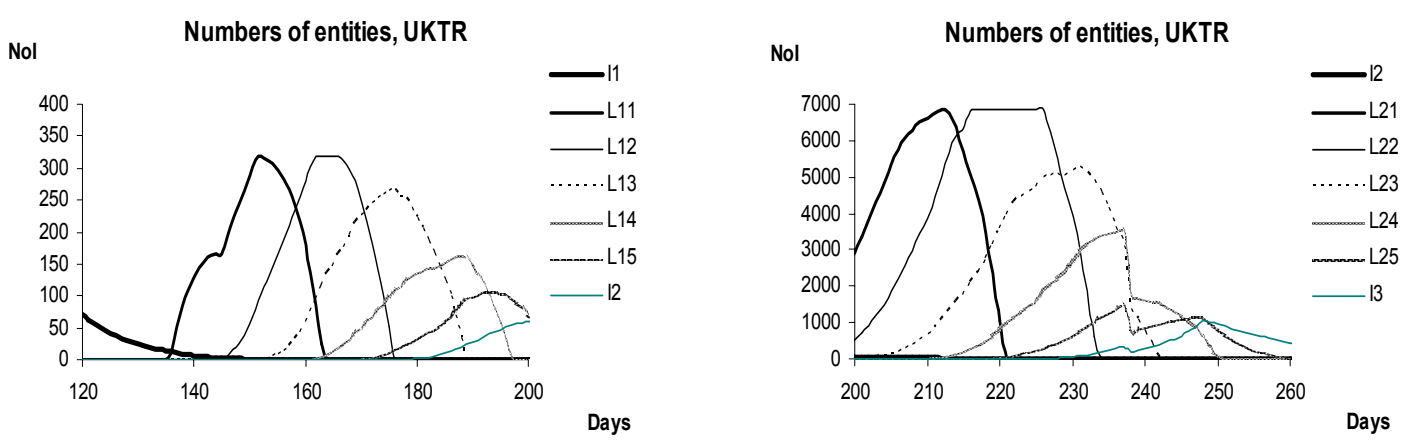

Figure 14. The numbers of Sycamore lace bug entities in each phenophase NoI $_{t}^{P h}$, predicted by the model for Budapest, for 1999 and for the $15^{\text {th }}$ years of the scenarios.

\section{Phenological pattern of Sycamore lace bug and climate change scenarios}

In order to compare the predictions of the model related to the different climate scenarios we have checked the model behaviour for the data of all the 30 years of each scenario. In what follows, we display the results of the $15^{\text {th }}$ year of each scenario, together with the ones of year 1999. First, we give the temperature data (Figure 11), then the values of activity terms $R_{t}$ (Figure 12), the smoothed characteristic functions $S S W_{t}^{P h}$ (Figure 13), the numbers of entities $N_{t}^{P h}$ (Figure 14), and finally the numbers of imagos and larvae per leaf (Figure 15).

\section{Discussion}

\section{Activity term $R_{t}$}

The activity terms of scenarios Base, GFDL2535 and GFDL5564 are very similar to the one of the empirical data of Budapest, 1999. Moreover, they do not even have extremely low values as the one of year 1999 (caused by some extremely hot days in the middle of summer). Thus, we expect the results of these scenarios quite similar to the one of year 1999. The weather data of scenarios UKHI and UKLO are such extreme that even at the beginning of spring it is unbearable for both Corythuca ciliata and Sycamore tree populations, that is to say the values of the activity the terms are very low in long periods of the vegetation. The activity term of scenario UKTR is similar to the one of year 1999, except at the end of August. Then, there is a short period with extreme weather conditions. For both population it is very hard to get over, though they are not threatened by extinction.

\section{Smoothed characteristic function $S S W_{t}^{P h}$}

As it was expected, the smoothed characteristic functions of scenarios Base, GFDL2535, GFDL5564 and UKTR are very similar to the one of the empirical data of Budapest, 1999. The smoothed characteristic functions of scenarios UKHI and UKLO are not very different in case of the first generation. The curves of $S S W_{t}^{P h}$ of the phenophases of the second generation are fatter and sluggish, the metamorphosis takes longer. (For scenario UKLO it is true for a greater extent.) Note, that the effect of the smoothed characteristic function can be detected only if the population survives. 
Budapest, 1999 (measured data)

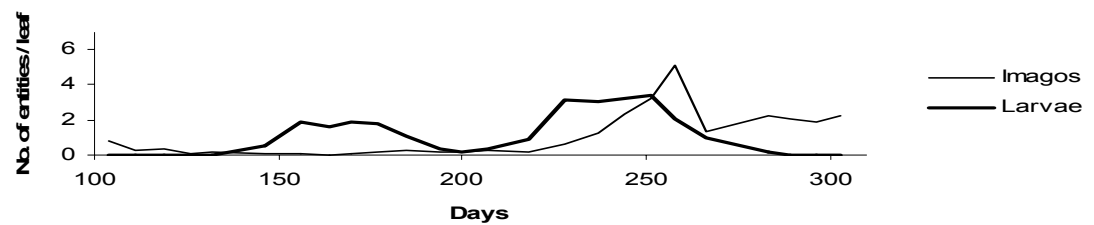

BASE (model prediction)

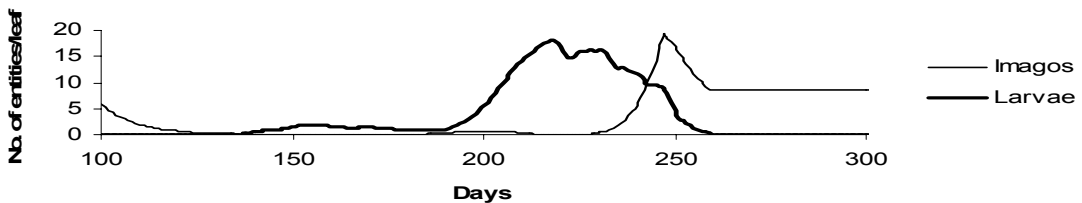

GFDL2534 (model prediction)

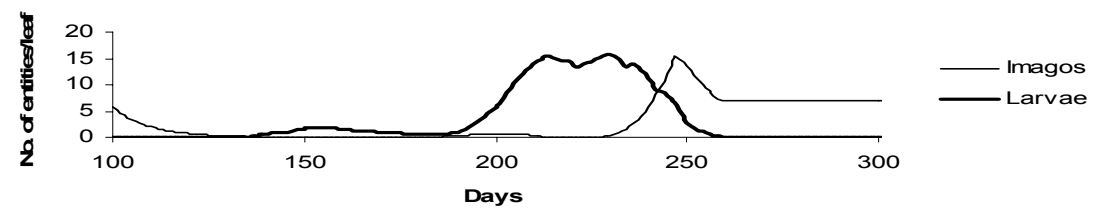

GFDL5564 (model prediction)

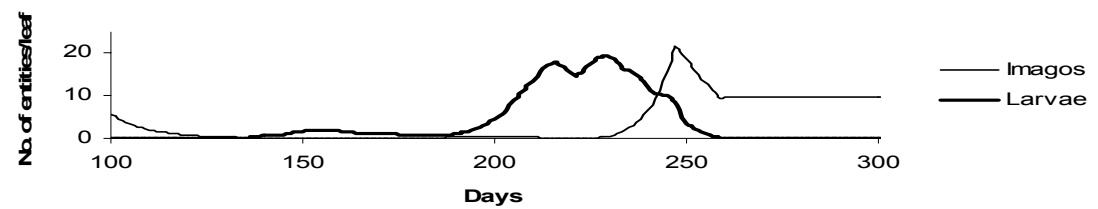

UKHI (model prediction)

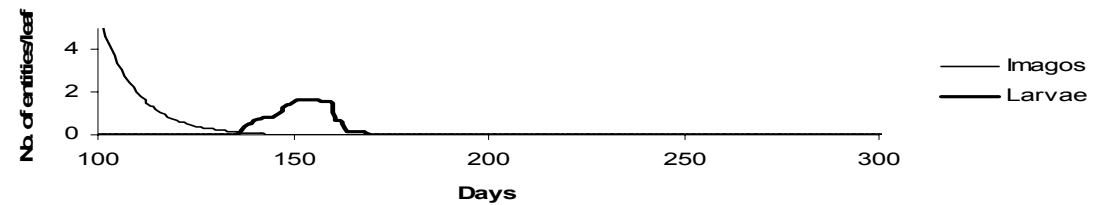

UKLO (model prediction)

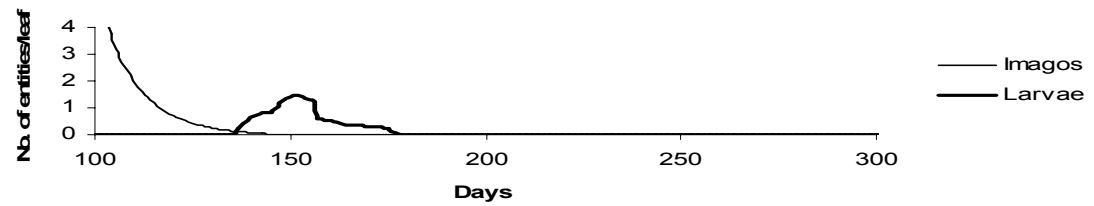

UKTR (model prediction)

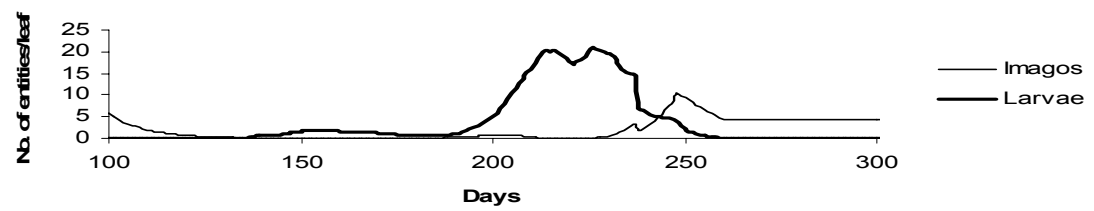

Figure 15. The numbers of Sycamore lace bug imagos and larvae per leaf, measured in Budapest, 1999 (uppermost figure), predicted by the model for Budapest, for 1999 (second figure) and for the $15^{\text {th }}$ years of the scenarios. 


\section{The number of entities $N o I_{t}^{P h}$}

The shapes of the characteristic curves of the functions $\mathrm{NoI}_{t}^{P h}$ are quite similar for scenarios Base, GFDL2535 and GFDL5564. The number of entities of the first generation increases $15-20 \%$ (compared with its value of 1999), while the one of the second generation increases about $500 \%$. The date of the first appearance of the phenophases are shifted 2-5 days earlier. The balance does not tip yet.

Considering curve of the number of entities for scenarios UKLO and UKHI we can observe that the entities of first generation practically extinct in their $L_{14}-L_{15}$ phase. We can assume that some entities can survive till their $I_{2}$ phase, but there is no chance for the second generation. This can be explained by the extreme weather.

The phenophases in the years of scenario UKTR begin slightly earlier. The effect of the extreme weather in August can be seen on the curves, a lot of entities die. Just after that, a balancing process can be observed.

\section{The numbers of imagos and larvae per leaf}

The numbers of the imagos of the first generation for scenarios Base, GFDL2535 and GFDL5564 are very similar to the one of the empirical data of Budapest, 1999, however, the numbers of the second generation are higher. The third generation appears a little later with a very speedy increase. Thus, the number of the third generation reaches its maximum 5-7 days earlier and the value of the maximum is about five times higher than the one of year 1999. These entities are going to winter.

The numbers of the larvae of the first generation for scenarios Base, GFDL2535 and GFDL5564 do not differ essentially from the one of the empirical data of Budapest, 1999 , but the second generation appears about 7 days earlier, the increase in number is quicker, the maximum is five times higher.

The larvae of the first generation for scenarios UKLO and UKHI extinct in their $L_{14}-L_{15}$ phase, as we have seen before.

The shapes of the characteristic curves of the numbers of the imagos and larvae per leaf for scenario UKTR is similar to the ones of scenarios Base, GFDL2535 and GFDL5564. The effect of the extreme weather in August can be seen on the curves. Just after that, a balancing process can be observed.

Acknowledgements. Our work was supported by the VAHAVA project of Hungarian Academy of Sciences, the KLIMAKKT project of NKFP "Jedlik Ányos" program, the FKFP 0087/2002 and OTKA T042583 projects and the ADAM project of EU.

\section{REFERENCES}

[1] Ammann, B. (2000): Biotic responses to rapid climatic changes; Introduction to a multidisciplinary study of the Younger Dryas and minor oscillations on an altitudinal transect in the Swiss Alps. - Palaeogeography, Palaeoclimatology, Palaeoecology 159(3-4): 191-201.

[2] Ayres, M.P., Lombardero, M.J. (2000): Assessing the consequences of global change for forest disturbance from herbivores and pathogens. - The Science of The Total Environment 262(3): 263-286.

[3] Barrow, E.M. (1993): Scenarios of climate changes for the European Community European Journal of Agronomy, 2(4): 247-260. 
[4] Barrow, E.M., Hulme, M., Semenov, M.A., Brooks, R.J. (2000): Climate change scenarios, In: Downing, T.E. (ed.) Climate Change, Climatic Variability and Agriculture in Europe - Environmental Change Institute, University of Oxford.

[5] Butterfield, R.E., Bindi, M., Brooks, R.J., Carter, T.R., Delécolle, R., Downing, T.E. (2000): Review and comparison od scaling-up methods, In: Downing, T.E. (ed.) Climate Change, Climatic Variability and Agriculture in Europe - Environmental Change Institute, University of Oxford

[6] Buxton, P.A. (2004): The effect of climatic conditions upon populations of insects. Transactions of the Royal Society of Tropical Medicine and Hygiene 26: 325-356.

[7] Chen, W., Chen, J., Cihlar, J. (2000): An integrated terrestrial ecosystem carbon-budget model based on changes in disturbance, climate, and atmospheric chemistry. - Ecological Modelling 135(1): 55-79.

[8] Conrad, K.F., Woiwod, I.P., Perry, J.N. (2002): Long-term decline in abundance and distribution of the garden tiger moth (Arctia caja) in Great Britain. - Biological Conservation 106(3): 329-337.

[9] Coops, N.C. Waring, R.H., Law, B.E. (2005): Assessing the past and future distribution and productivity of ponderosa pine in the Pacific Northwest using a process model, 3-PG. - Ecological Modelling 183(1): 107-124.

[10] Crookston, N.L., Dixon, G. E. (2005): The forest vegetation simulator: A review of its structure, content, and applications. - Computers and Electronics in Agriculture 49(1): 60 80 .

[11] Dyck, M. van (1999): Keyword Reference Guide for the Forest Vegetation Simulator. WO-TM Service Center, USDA Forest Service. Fort Collins, CO. September 1, 1996. $134 \mathrm{pp}$.

[12] Elias, S.A., Devender, T.R. van (1990): Fossil insect evidence for late Quaternary climatic change in the Big Bend region, Chihuahuan Desert, Texas. - Quaternary Research 34(2): 249-261.

[13] Fleming, R.A., Barclay, H.J., Candau , J.N. (2002): Scaling-up an autoregressive timeseries model (of spruce budworm population dynamics) changes its qualitative behaviour. - Ecological Modelling 149(1-2): 127-142.

[14] Flynn, D.F.B., Sudderth, E.A., Bazzaz, F.A. (2005): Effects of aphid herbivory on biomass and leaf-level physiology of Solanum dulcamara under elevated temperature and $\mathrm{CO}_{2}$. - Environmental and Experimental Botany (in press).

[15] Fodor N., Kovács G.J. (2005): Sensitivity of crop models to the inaccuracy of meteorological observations. - Physics and Chemistry of the Earth. Special issue: Agrometeorology. Dunkel, Z. (ed.) Elsevier Science, Amsterdam, The Netherlands. 30(13): $53-58$.

[16] Fodor N., Máthéné-Gáspár G., Pokovai K., Kovács G.J. (2002): 4M - software package for modelling cropping systems. - European J. of Agr. 18(3-4): 389-393.

[17] Fodor N., Rajkai K. (2004): Talajfizikai tulajdonságok becslése és modellezésben való alkalmazásuk. - Agrokémia és Talajtan 53: 225-238

[18] Fuhrer, J. (2003): Agroecosystem responses to combinations of elevated $\mathrm{CO}_{2}$, ozone, and global climate change. - Agriculture, Ecosystems \& Environment 97(1-3): 1-20.

[19] Hanson, P.J., Weltzin, J.F. (2000): Drought disturbance from climate change: response of United States forests. - The Science of The Total Environment 262(3): 205-220.

[20] Harnos, Zs., Bussay, A., Harnos, N. (2000): Modelling climate change impacts on wheat and potato in Hungary - In: Downing, T.E. (ed.) Climate Change, Climatic Variability and Agriculture in Europe - Environmental Change Institute, University of Oxford.

[21] Harnos, N. (2003): A klímaváltozás hatásának szimulációs vizsgálata őszi búza produkciójára, - "Agro-21" Füzetek 31: 56-73.

[22] Hufnagel, L., Mészáros, Z. (1999): Lehetséges természetvédelmi problémák, a faunánkra idegen állatfajok növényvédelmi célú mesterséges betelepítésével kapcsolatban Növényvédelem, 35. évf, 11. sz. 563-565 
[23] Hufnagel, L., Mészáros, Z. (2000): Viszontválasz egy válaszcikk nyomán Növényvédelem, 36. évf 1. sz 9-11.

[24] IPCC (1996): Climate Change 1995: The Science of Climate Change, Cambridge University Press, Cambridge.

[25] Klok, C.J., Chown, S.L. (2001): Critical thermal limits, temperature tolerance and water balance of a sub-Antarctic kelp fly, Paractora dreuxi (Diptera: Helcomyzidae). - Journal of Insect Physiology 47(1): 95-109.

[26] Kovács G.J. (1998): Estimation of the Effect of Global Warming on Yields and Environment of Arable Crops in Hungary. - Agrokémia és Talajtan 47(1-4.): 133-144.

[27] Kovács G.J. (1997): Nitrate leaching study in a long term experiment; combination of field- and simulation experiments. - Agrokémia és talajtan 46(1-4): 135-143.

[28] Kovács G.J. (2004): Application of models to development of decision support tools. - In: Improving the Balance Between Economic Agricultural Production and Environmental Quality through Enhanced Decision Making, Hatfield, J.L. (ed.) OECD. Ames, USA

[29] Kovács, G.J. (1995) Application of CERES model in soil science and agricultural chemistry. - Agrokémia és Talajtan. 44(1-2): 249-262.

[30] Kovács, G.J., T. Németh (1995c): Modeling of nitrogen regime based on long term field experiments. - Agrokémia és Talajtan. 44(3-4): 545-551.

[31] Kovács, G.J., T. Németh, J.T. Ritchie (1995a): Testing Simulation Models for Assessment of Crop Production and Nitrate Leaching in Hungary. - Agricultural Systems, (ELSEVIER Sci. Ld., Oxford, England) 49(4): 385-397.

[32] Kovács, G.J., T.Németh (1995b) Modeling of yield and nitrate accumulation comparing with measurements in long term experiments. - Agrokémia és Talajtan. 44(1-2): 89-100.

[33] Ladányi, M., Horváth, L., Gaál, M., Hufnagel, L. (2003): An agro-ecological simulation model system. - Applied Ecology and Environmental Research, 1(1-2): 47-74.

[34] Ladányi, M., Hufnagel, L. (2003): A phenology model embedded in an ecosystem model for agroecological processes. - In: Harnos, Zs. et al. (eds) EFITA 2003 Conference, Debrecen-Budapest, Hungary. Information technology for a better agri-food sector, environment and rural living, pp. 876-881.

[35] Láng, I. (2003): Bevezető gondolatok "A globális klímaváltozással összefüggő hazai hatások és az arra adandó válaszok" címü MTA-KvVM közös kutatási projekthez, "Agro-21" Füzetek 31: 3-8.

[36] Lemdahl, G. (1991): A rapid climatic change at the end of the Younger Dryas in south Sweden - palaeoclimatic and palaeoenvironmental reconstructions based on fossil insect assemblages. - Palaeogeog., Palaeoclimat., Palaeoecology 83(4): 313-331.

[37] Lemdahl, G. (2000): Lateglacial and Early Holocene insect assemblages from sites at different altitudes in the Swiss Alps - implications on climate and environment. Palaeogeography, Palaeoclimatology, Palaeoecology 159(3-4): 293-312.

[38] Lenteren, J.C. van (2000): A greenhouse without pesticides: fact or fantasy? - Crop Protection 19(6): 375-384.

[39] Máthé-Gáspár G., Fodor N., Pokovai K., Kovács G.J. (2005): Crop modelling as a tool to separate the influences of the soil and weather on crop yields. - Physics and Chemistry of the Earth. Special issue: Agrometeorology. Dunkel, Z. (ed.) Elsevier Science, Amsterdam, The Netherlands. 30(1-3): 165-170.

[40] McKibben, G.H., Willers, J.L. Smith, J.W., Wagner, T.L. (1991): Stochastic model for studying boll weevil dispersal. - Environ.Ent. 20(5) pp.1327-1332.

[41] Mols, P.J.M. (1990): Forecasting orchard pests for adequate timing of control measures. Proc. Exp. \& Appl. Entomol., NEV. Amsterdam 1: 75-81.

[42] Mols, P.J.M. (1992): Forecasting an indispensable port of IPM in apple orchards. - Acta Phytop. Entom. H. 27(1-4): 449-460.

[43] Norango, S.E., Sawyer, A.J. (1989): A simulation model of northern corn rootworm. Diabrotica barberi, population dynamics, oviposition: significance of host-plant phenology. - Can. Ent. 121: 169-191. 
[44] Öszi, B., Ladányi, M., Hufnagel, L. (2005): Population dynamics of the sycamore lace bug, Corythucha ciliata (Say) (heteroptera: tingidae) in Hungary. -Applied Ecology and Environmental Research, 4(1): 135-150.

[45] Paegle and McLawhorn (1983): Correlation of nocturnal thunderstorms and boundarylayer convergence. - Monthly Weather Review 101: 877-933.

[46] Porter, J.H., Parry, M.L., Carter, T.R. (1991): The potential effects of climatic change on agricultural insect pests. - Agricultural and Forest Meteorology 57(1-3): 221-240.

[47] Powell, J.A., Logan, J.A (2005): Insect seasonality: circle map analysis of temperaturedriven life cycles. - Theoretical Population Biology 67(3): 161-179.

[48] Schwert, D.P., Anderson, T.W., Morgan, A., Morgan, A. V., Karrow, P. F. (1985): Changes in late Quaternary vegetation and insect communities in southwestern Ontario. Quaternary Research, 23(2): 205-226.

[49] Seppelt, R. (1999): Applications of optimum control theory to agro-ecological modelling. - Ecological Modelling 121(2-3): 161-183.

[50] Seppelt, R. (2000): Regionalised optimum control problems for agro-ecosystem management. - Ecological Modelling. 131(2-3): 121-132.

[51] Seppelt, R. (2001): Agro-ecosystem Management. - In: J. Pinter (ed.): Global Optimization \& Selected Case Studies, Kluver, Dordrecht, New York.

[52] Sharon, R., Degani, G., Warburg, M. (2001): Comparing the soil macro-fauna in two oakwood forests: does community structure differ under similar ambient conditions? Pedobiologia 45(4): 355-366.

[53] Strand, J.F. (2000): Some agrometeorological aspects of pest and disease management for the 21st century. - Agricultural and Forest Meteorology 103(1-2): 73-82.

[54] Varga-Haszonits, Z. (2003): Az éghajlatváltozás mezőgazdasági hatásának elemzése, éghajlati szcenáriók, - "Agro-21" Füzetek 31: 9-28.

[55] Vásárhelyi, T., Hufnagel, L. (1990): A platánfa légies átka. - Élet és Tudomány 1990(30): 940-942.

[56] Volney, W.J.A., Fleming, R.A. (2000): Climate change and impacts of boreal forest insects. - Agriculture, Ecosystems \& Environment 82(1-3): 283-294.

[57] Whinam, J., Chilcott, N., Bergstrom, D.M. (2005): Subantarctic hitchhikers: expeditioners as vectors for the introduction of alien organisms. - Biological Conservation 121(2): 207-219. 